\title{
ISU GERAKAN SOSIAL BARU: TEMPAT NASI GRATIS BANDUNG
}

\author{
Andina Prasetya ${ }^{1}$, Yogi Suprayogi Sugandi ${ }^{2}$ \\ ${ }^{1}$ Program Studi Pascasarjana Fisip Universitas Padjajaran \\ andinaprasetya15@gmail.com
}

\begin{abstract}
ABSTRAK
Penelitian ini bertujuan untuk mendeskripsikan dan mengidentifikasi mengenai isu gerakan sosial baru yang berbentuk Tempat Nasi Gratis Bandung, jenis penelitian yang digunakan adalah penelitian deskriptif kualitatif. Teknik pengumpulan data yang digunakan dalam penelitian ini adalah studi kepustakaan. Saat ini semua orang dapat melakukan kegiatan gerakan atau aksi sosial dengan cara apa pun. Salah satunya dengan bersedekah nasi, berbagi kebahagiaan dengan sesama, ketika memiliki rejeki yang lebih untuk beramal masyarakat Bandung bisa menyalurkannya melalui sebuah etalase dengan tinggi 1 meter dan lebar $50 \mathrm{~cm}$ untuk menyimpan nasi bungkus atau nasi kotak dengan lauk pauknya serta air mineral. Etalase yang diberi nama Tempat Nasi Gratis atau TNG yang berada di Bandung ditempatkan dilokasi-lokasi yang strategis dengan konsep siapapun boleh mengambil dan siapapun boleh mengisi. Nasi kotak yang tersedia dietalase, tidak hanya untuk masyarakat miskin kota, melainkan warga yang kehabisan uang, ataupun warga yang kesulitan mendapatkan makanan saat di perjalanan. Gerakan sosial baru ini digagas oleh seorang warga Bandung bernama Rochsan rudyanto.
\end{abstract}

Kata kunci: Gerakan sosial, nasi gratis dan sedekah

\begin{abstract}
This study aims to describe and identify the issue of new social movements in the form of Free Rice Place Bandung, the type of research used is qualitative descriptive research. The data collection technique used in this study is library research. At present everyone can carry out activities of movement or social action in any way. One of them is giving charity rice, sharing happiness with others, when having more fortune to charity the people of Bandung can channel it through a display window with a height of 1 meter and a width of $50 \mathrm{~cm}$ to store rice or rice boxes with side dishes and mineral water. A storefront named Place Free Rice or TNG in Bandung is placed in strategic locations with the concept that anyone can take and anyone can fill. Box rice available in dietalase, not only for the urban poor, but residents who run out of money, or residents who have difficulty getting food while on the trip. This new social movement was initiated by a Bandung citizen named Rochsan rudyanto.
\end{abstract}

Keywords: Social movements, free rice and alms

2 Prodi Pascasarjana Sosiologi, Fakultas Ilmu Sosial dan Ilmu Politik, Universitas Padjadjaran yogi.suprayogi@unpad.ac.id 


\section{PENDAHULUAN}

Berbicara tentang gerakan sosial (Social Movement) maka tidak dapat dipisahkan dari perkembangan kapitalisme dunia, karena pada umumnya gerakan sosial lahir untuk merespon akan diskursus kapitalisme. Dan walaupun gerakan sosial merupakan gejala yang baru dalam ilmu sosial, namum gerakan sosial sudah ada sejak lama yaitu mulai abad 18, yaitu pada saat gereja Methodis di Amerika dan Inggris menjadi sebuah bentuk gerakan sosial yang berbasis Agama.

Di abad 19 terdapat gerakan sosial Internasional (The International Socialist Movement) yang tumbuh dan berkembang di berbagai tempat di Eropa juga di anggap sebagai gerakan sosial. Dan pada abad ke 20 juga terdapat gerakan hak-hak sipil di Eropa dan Amerika yang menentukan sejarah panjang diskriminasi rasial di negeri tersebut. Di tahun 1970 an gerakan anti perang dan gerakan anti kemapanan yang menggunjang kehidupan Amerika juga dianggap sebagai inspirasi dari gerakan sosial.

Gerakan sosial (social movement) merupakan fenomena partisipasi sosial (masyarakat) dalam hubungannya dengan entitas-entitas eksternal. Istilah ini memiliki beberapa definisi, namun secara umum dapat dilihat sebagai instrumen hubungan kekuasaan antara masyarakat dan entitas yang lebih berkuasa (powerful). Masyarakat cenderung memiliki kekuatan yang relatif lemah (powerless) dibandingkan entitas-entitas yang dominan, seperti negara atau swasta (bisnis). Gerakan sosial menjadi instrumen yang efisien dalam menyuarakan kepentingan masyarakat. Dengan kata lain gerakan sosial merupakan pengeras suara masyarakat sehingga kepentingan dan keinginan mereka terdengar.

Gerakan Sosial (social Movement) adalah aktivitas sosial berupa gerakan atau tindakan sekelompok orang yang bersifat informal atau organisasi, Sebuah Gerakan sosial biasa berfokus pada isu-isu sosial dan politik dengan melaksanakan, menolak, atau mengkampanyekan sebuah perubahan sosial (Purboningsih, 2015).

Kamanto Sunarto (2004) bahwa gerakan sosial (politik) adalah perilaku kolektif yang ditandai kepentingan bersama dan tujuan jangka panjang, yaitu untuk mengubah ataupun mempertahankan masyarakat atauinstitusi yang ada di dalamnya.

Robert Mirsel (2004) bahwa gerakan kemasyarakatan adalah seperangkat keyakinan dan tindakan yang tak terlembaga (noninstitutionalised) yang dilakukan sekelompok orang untuk memajukan atau menghalangi perubahan di dalam suatumasyarakat.Tidak terlembaga mengandung arti mereka cenderung tidak diakui sebagai sesuatu yang berlaku umum secara luas dan sah di dalam suatu masyarakat. 
Ciri-ciri gerakan sosial lama yaitu memiliki struktur organisasi, ada dasar pemikiran yang digunakan sebagai landasan perjuangan atau ideologi, dan harus memiliki identitas yang jelas dan dikenal oleh khalayak umum. Contoh organisasi ini adalah kelompok-kelompok mahasiswa, kelompok agama, dan kelompok masyarakat atau ormas, buruh. Gerakan sosial lama mengatakan bahwa politik selalu berbicara kepentingan orang banyak yang harus diperjuangkan ke pemerintah. Sering kali gerakan sosial ini dalam pergerakannya sangat bersifat revolusioner dalam melakukan aksinya. Mereka dalam melakukan aksinya dilatarbelakangi oleh kegelisahaan atau kekecewaan terhadap kebijakan maupun pemerintahan.

Dalam menilai gerakan sosial baru, Touraine menekankan pentingnya tindakan sosial, bahwa aksi yang dilakukan individu-individu dalam bentuk gerakan sosial merupakan suatu upaya untuk memproduksi dan mentransformasi struktur dan tatanan sosial yang ada. Dan aksi sosial dalam gerakan sosial ini dilihat sebagai tindakan yang normal menuju pada satu perubahan yang diharap oleh masyarakat. Dalam tulisanya, The Self Production of Society (1973), Touraine menyatakan bahwa masyarakat itu bukan apa-apa selain dari tindakan sosial, karena tatanan sosial itu tidak memiliki jaminan metasosial demi eksistensinya (A.Touraine, 1973).

Gerakan Sosial Baru (New Social Movement) adalah bentuk lain dari gerakan sosial itu sendiri. Ciri menonjol Gerakan Sosial Baru yang dianggap membedakannya dari gerakan sosial lama, dapat dinyatakan sebagai berikut (Singh, 2010).

Gerakan Sosial Baru menanggalkan orientasi ideologis yang melekat kuat padagerakan sosial lama, sebagaimana sering dinyatakan dalam ungkapan-ungkapan antikapitalisme, revolusi kelas, dan perjuangan kelas. Gerakan sosial baru menolak semua asumsi Marxian bahwa semua perjuangan dan pengelompokan didasarkan atas konsep kelas.

Taktik dan pengorganisasian Gerakan Sosial Baru umumnya tidak lagi mengikuti model pengorganisasian serikat buruh industri dan model politik kepartaian. Gerakan sosial baru lebih memilih hubungan di luar politik normal, menggunakan taktik yang mengganggu (disruptive), dan memobilisasi opini publik untuk mendapatkan daya tawar politik.

Partisipan Gerakan Sosial Baru berasal dari berbagai basis sosial yang memiliki kategorikategori sosial seperti gender, pendidikan, okupasi dan kelas. Mereka tidak terkotakkan pada penggolongan tertentu seperti kaum proletar, petani, dan buruh, seperti aktor-aktor gerakan sosial lama yang biasanya melibatkan kaum marginal dan teralienasi. Para aktor GSB berjuang melintasi sekat-sekat sosial demi kepentingan kemanusiaan.

Medan atau area aksi-aksi Gerakan sosial baru juga melintasi batas-batas region: dari aras lokal hingga internasional, sehingga mewujud menjadi gerakan transnasional. Karena itu pula

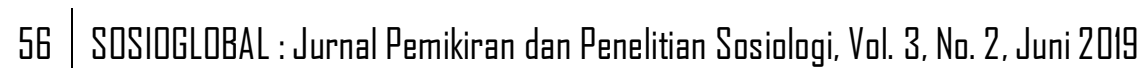


strategi dan cara mobilisasi mereka pun bersifat global. Dalam hal ini, gerakan sosial baru melihatkan wajah transmanusia dengan mendukung kelestarian alam di mana manusia merupakan salah satu bagiannya. Ini secara jelas terpantul dari gerakan-gerakan anti nuklir, ekologi, perdamaian, dan sebagainya, yang menghamparkan kebersamaan warga dari beragam nasionalitas, kebudayaan dan sistem politik. Gerakan sosial baru memperlihatkan wajah gerakan sosial yang plural.

Dasar dari gerakan sosial baru yang diungkapkan oleh (Budiarjo, 2010) adalah "protes". Mereka sangat kritis terhadap cara-cara berpolitik dari para birokrat, dan merasa terasingkan dari masyarakat. Mereka menginginkan desentralisasi kekuasaan Negara dan pmerintah, partisipasi dalam peningkatan swadaya masyarakat, terutama masyarakat lokal. Tujuannya antara lain meningkatkan kualitas hidup. Salah satu caranya adalah dengan mendirikan berbagai kelompok yang peduli pada masalah-masalah baru seperti lingkungan, gerakan perempuan, hak asasi manusia, dan gerakan antinuklir.

Selain itu, gerakan sosial baru ini lebih menekankan kebebasan pada gerakan mereka itu sendiri seperti tidak memiliki struktur organisasi, tidak terbirokratisasi, mempunyai kepentingan atau isu perjuangan yang sama. Gerakan sosial baru akan membentuk sebuah identitas politik tersendiri pada anggotanya dengan fokus usaha untuk menekan pemerintah lebih perhatian di luar kepentingan materil.

Sebuah etalase makanan yang bertuliskan Tempat Nasi Gratis (TNG) di Bandung menjadi pembicaraan masyarakat baik di lingkungan maupun media sosial. Kehadiran TNG dinilai memberikan manfaat bagi masyarakat Bandung terkhusus yang membutuhkan. TNG dengan slogan 'Siapapun Boleh Mengambil, Siapapun Boleh Mengisi' digagas oleh seorang warga Bandung bernama Rochsan karena motivasi dengan viralnya gerakan serupa di beberapa wilayah. Sehingga dia bersama rekan-rekannya berinisiatif mengikuti gerakan tersebut di Kota Bandung. , beberapa masyarakat merasa sangat terpanggil dan terfasilitasi dengan adanya TNG ini. Karena memudahkan dalam memberikan sebagian hartanya kepada warga di semua kalangan yang membutuhkan.

\section{METODE PENELITIAN}

Dalam penulisan ini digunakan pendekataan kualitatif dengan metode deskriptif yang digunakan untuk menjelaskan, menggambarkan, dan mengungkapkan suatu masalah dari objek yang diteliti, penulis juga melakukan wawancara dan observasi serta studi pustaka dari berbagai literature. Metode studi pustaka merupakan suatu metode analisa data sekunder yang relavan dengan topik yang ingin dikaji. (sugiyono, 2012) studi kepustakaan merupakan suatu kajian 
yang berkaitan dengan kajian teoritis dengan menggunakan referensi lain (sekunder) yang relevan dan saling berkaitan dengan nilai, budaya, dan norma yang berkembang pada situasi sosial yang hendak diteliti, selain itu studi kepustakaan sangat penting dalam melakukan penelitian dikarenakan penelitian tidak akan lepas dari penggunaan literatur-literatur Ilmiah sebelumnya.

Bahan dari kajian pustaka yang digunakan dalam penulisan ini diperoleh melalui penelusuran dari berbagai sumber, seperti jurnal ilmiah, buku teks, dan hasil penelitian ilmiah lainnya yang berkaitan dengan tema maupun judul dalam tulisan ini. Setelah memperoleh bahan atau referensi yang relevan selanjutnya penulis memahami, menyusun, dan menganalisis sehingga menjadi suatu tulisan ilmiah dan membentuk suatu struktur penulisan yang padu.

\section{PEMBAHASAN}

Teori gerakan sosial baru muncul sebagai kritik terhadap teori lama yang selalu ada dalam wacana idiologis kelas. Gerakan sosial baru adalah gerakan yang lebih berorientasi isu dan tidak tertarik pada gagasan revolusi. Gerakan sosial baru lebih bersifat plural, yaitu mulai dari gerakan anti rasisme, anti nuklir, feminisme, kebebasan sipil dan lain sebagainya. (Suharko, 2006)

Gerakan sosial baru melihat pada suatu konsepsi yang membedakannya dengan konsep gerakan sosial yang lama dimana gerakan sosial lama lebih politis, melibatkan aksi massa serta berorientasi kelas. Gerakan sosial baru lebih cenderung dipahami sebagai gerakan yang kultural, tidak melibatkan aksi massa, lebih dekat dengan issu sehari-hari, dalam hal ini adalah aksi sosial masyarakat dalam bentuk Tempat Nasi Gratis Bandug (Rahmat, 2017).

Gerakan sosial baru adalah gerakan yang lebih berorientasi isu dan tidaktertarik pada gagasan revolusi. Dan tampilan dari gerakan sosial baru lebih bersifat plural, yaitu mulaidari gerakan anti rasisme, anti nuklir, feminisme, kebebasan sipil dan lain sebagainya. Gerakan sosialbaru beranggapan bahwa di era kapitalisme liberal saat ini perlawanan timbul tidak hanya dari gerakan buruh, melainkan dari mereka yang tidak terlibat secara langsung dalam sistem produksi seperti misalnya, mahasiswa, kaum urban, kaum menengah. Karena system kapitalisme telah merugikan masyarakat yang berada di luar sistem produksi. Ada beberapa hal yang baru dari gerakan sosial, sepertiberubahnya media hubung antara masyarakat sipil dan negara berubahnya tatanan dan representasi masyarakat kontemporer itu sendiri.

Gerakan sosial baru menaruh konsepsi idiologis mereka pada asumsi bahwa masyarakat sipil tengah meluruh, ruang sosialnya telah mengalami penyempitan dan digerogoti oleh kemampuan kontrol Negara dan secara radikal Gerakan sosial baru mengubah paradigma 58 | SOSIOGLLBAL : Jurnal Pemikiran dan Penelitian Susiologi, Vol. 3, №. 2, Juni 2019 
marxis yang menjelaskan konflik dan kontradiksi dalam istilah kelas dan konflik kelas. Sehingga gerakan sosial baru didefenisikan oleh tampilan gerakan yang non kelas serta pusat perhatian yang non materialistik, karena gerakan social baru tidak ditentukan oleh latar belakang kelas, maka mengabaikan organisasi serikat buruh industri dan model politik kepartaian, tetapi lebih melibatkan politik akar rumput, aksi-aksi akar rumput. berbeda dengan gerakan klasik, struktur gerakan sosial baru didefenisikan oleh pluralitas cita-cita, tujuan , kehendak dan orientasi heterogenitas basis sosial mereka. Gerakan sosial baru pada umumnya merespon isu-isu yang bersumber dari masyarakat sipil, membidik domain sosial masyarakat sipil ketimbang perekonomian atau negara, dan membangkitkan isu-isu sehubungan demoralisasi struktur kehidupan sehari-hari dan memusatkan perhatian pada bentuk komunikasi dan identitas kolektif.

Jean Cohen (1985) menyatakan Gerakan Sosial Baru membatasi diri dalam empat pengertian yaitu,(a) aktor-aktor gerakan sosial baru tidak berjuang demi kembalinya komunitas-komunitas utopia tak terjangkau dimasa lalu (b) aktornya berjuang untuk otonomi, pluralitas (c) para aktornya melakukan upaya sadar untuk belajar dari pengalaman masa lalu, untuk merelatifkan nilai-nilai mereka melalui penalaran, (d) para aktornya mempertimbangkan keadaan formal negara dan ekonomi pasar.

Dengan demikian tujuan dari gerakan sosial baru adalah untuk menata kembali relasi negara, masyarakat dan perekonomian dan untuk menciptakan ruang publik yang di dalamnya terdapat wacana demokratis otonomi dan kebebasan individual.

Komponen paling umum dari tindakan sosial terletak dalam sistem nilai. Komponen ini begitu umum sehingga tidak punya spesifikasi norma, organisasi, atau fasilitas tertentu untuk mewujudkan tujuan-tujuannya. Nilai itu, misalnya, demokrasi, yang secara umum menjadi ideologi gerakan mahasiswa 1998. Meskipun ada elemen-elemen yang sama dalam definisi demokrasi di berbagai negara seperti sistem representasi, kekuasaan mayoritas, dan sebagainya, nilai ini tidak memberikan pengaturan institusional yang persis.

Norma bersifat lebih spesifik ketimbang nilai. Norma bisa bersifat formal, seperti ditemukan dalam peraturan hukum, bisa juga informal. Namun nilai dan norma saja belum menentukan bentuk organisasi tindakan manusia, seperti: siapa yang menjadi pelaksana upaya pencapaian tujuan ini, bagaimana tindakan-tindakan para pelaksana ini distrukturkan dalam peran dan organisasi, semacam: gerakan mahasiswa, pers mahasiswa, dan sebagainya. Mobilisasi motivasi ke dalam tindakan terorganisasi adalah komponen ketiga untuk mewujudkan tujuan nilai dan norma tadi 


\section{Andina Prasetya}

Komponen terakhir adalah fasilitas situasional. Ini bisa berupa sarana yang mendukung, bisa juga hambatan yang mempersulit pencapaian tujuan konkret dalam konteks peran dan organisasi. Komponen terakhir ini mengacu ke pengetahuan seorang aktor tentang peluang dan keterbatasan lingkungan, dan dalam sejumlah kasus, tentang pengetahuan terhadap kemampuannya sendiri dalam mempengaruhi lingkungan. Pengetahuan ini bersifat relatif, bagi kemungkinan pencapaian tujuan yang menjadi bagian dari keanggotaannya pada suatu peran atau organisasi.

Semua orang dapat melakukan kegiatan gerakan sosial dengan cara apa pun. Salah satunya dengan bersedekah nasi, berbagi kebahagiaan dengan sesama. Sedekah merupakan bagian dari kedermawanan dalam konteks masyarakat muslim sebagai wujud kecintaan hamba terhadap nikmat Allah yang telah diberikan kepadanya sehingga seorang hamba rela menyisihkan sebagian hartanya untuk kepentingan agama baik dalam rangka membantu sesama maupun perjuangan dakwah Islam. Masyarakat indonesia yang mayoritas penduduknya beragama Islam, sedekah sudah seharusnya menjadi kewajiban yang ditunaikan oleh setiap individu yang muslim. Sedekah merupakan ibadah yang mempunyai dimensi ganda, yaitu horizontal dan vertikal. Dimensi horizontal berkaitan dengan bentuk dan pola hubungan antar manusia, sedangkan dimensi vertikal berkaitan dengan hubungan manusia dengan Tuhan. Sedekah bisa disebut sebagai ibadah sosial. Ibadah sosial merupakan ibadah yang mempunyai efek langsung dengan konteks kehidupan masyarakat sekitar, mengandung nilai gotong royong dan tanggung jawab sosial sehingga dapat diharapkan dapat meratakan pendapatan ekonomi serta menghapus kemiskinan dalam masyarakat.

Sedekah atau dalam bahasa Arab shodaqoh yang berarti suatu pemberian yang diberikan oleh seorang muslim kepada orang lain secara spontan dan sukarela tanpa dibatasi oleh waktu dan jumlah tertentu. Juga berarti suatu pemberian yang diberikan oleh seseorang sebagai kebajikan 4 yang mengharapkan ridho Allah SWT dan pahala semata 1 . Shadaqoh berasal dari kata shadaqa yang berarti benar. Makna sedekah secara bahasa adalah membenarkan sesuatu (Iskandar, 1994). Rasulullah bersabda, "Jika anak adam meninggal dunia, maka terputuslah semua amalannya, kecuali tiga perkara, sodaqoh jariyah, ilmu yang bermanfaat dan anak sholeh yang mendoa'aknnya" (HR. Muslim).

Sedekah dalam kaitannya menyisihkan sebagian pendapatan dari usaha yang dikelola dari peserta tersebut dilakukan supaya mendapatkan kemudahan dalam proses usaha yang diharapkan. Kelancaran usaha yang ditekuni tidak lepas dari bagaimana cara seseorang tersebut mempunyai aturan atau manajemen setiap kegiatan usahanya. Baik dari modal usaha, proses 
produksi, sampai hasil produksi sudah diketahui dengan matang dengan tujuan dalam meningkatkan keuntungan.

Orang yang suka bersedekah adalah orang yang benar pengakuan imannya. Menurut syariat, pengertian sedekah sama dengan pengertian infaq, termasuk juga hukum dan ketentuanketentuannya. Hanya saja, jika infaq berkaitan dengan materi, sedekah memiliki arti lebih luas dari sekedar material, misal senyum itu sedekah. Dari hal ini yang perlu diperhatikan adalah jika seseorang telah berzakat tetapi masih memiliki kelebihan harta, sangat dianjurkan sekali untuk berinfaq atau bersedekah dalam beberapa ungkapan al-Quran.

Undang-undang No. 20 tahun 2003 tentang Sistem Pendidikan Nasional Bab II Pasal 3 menyebutkan bahwa: Pendidikan nasional berfungsi mengembangkan kemampuan dan membentuk watak serta peradaban bangsa yang bermartabat dalam rangka mencerdaskan kehidupan bangsa, bertujuan untuk berkembangnya potensi peserta didik agar menjadi manusia yang beriman dan bertakwa kepada Tuhan Yang Maha Esa, berakhlak mulia, sehat, berilmu, cakap, kreatif, mandiri, dan menjadi warga negara yang demokratis serta bertanggung jawab (Muhammad bin Salih, 2008: 2) Islam memerintahkan kepada umatnya untuk suka memberi, dan Rasulullah SAW merupakan teladan bagi umat Islam untuk mencintai perilaku berderma kepada siapa saja.

Orang yang gemar bersedekah adalah mereka yang memahami arti kehidupan dalam hidupnya. Di dalam rumus hidupnya, orang yang gemar bersedekah lebih memahami makna pentingnya berbagi kepada sesama, daripada suka menuntut dan meminta yang seringkali bukan haknya. Orang yang kaya mendapatkan kemudahan dan kesempatan yang luas dari Allah untuk mengeluarkan sebagian hartanya bagi orang-orang yang membutuhkan. Sedekah akan membuat amalan ibadah mereka semakin lengkap di mata Allah SWT, dan semakin sempurna untuk kehidupan sosialnya ditengah masyarakat luas.

Kegiatan infak dan sedekah ini merupakan kegiatan berupa infak harian yang bersifat lunak (sunah) dan infak jumat (wajib) dan dalam memberikan infaq tidak ditentukan nominalnya, yang mana setelah dana terkumpul diserahkan ke bagian bendahara. Dana yang telah terkumpul dialokasikan untuk siswa yang terkena musibah, siswa sakit, kematian baik dari siswa maupun wali siswa, sumbangan sosial berupa sembako bagi janda tua dan kaum dhuafa, bagi masyarakat yang tidak mampu (fakir miskin) dan kaum lemah.

Bersedekah bisa meningkatkan kepedulian sosial, karena manusia hidup di dunia ini pasti membutuhkan sesama. Manusia bisa dikatakan kaya karena adanya orang miskin dan itulah pentingnya bersedekah. Bersedekah akan membuat jalinan silaturahim dengan sesama bisa 
tersambung, dengan silaturahim yang baik maka manusia bisa menjaga sumber rizki, karena orang yang gemar menyambung tali silaturahim akan diluaskan rezekinya.

Bersedekah akan membuat hidup manusia sederhana dan rendah hati. Sedekah yang ditunaikan dari sebagian harta terbaik, akan mendidik seseorang menjadi pribadi yang rendah hati dan belajar hidup bersahaja. Orang yang gemar bersedekah berarti mengoptimalkan keberadaan harta benda, menghindari hidup berfoya-foya, hura-hura, boros sekaligus mubadzir. Bersedekah akan selalu mengingatkan manusia untuk hidup hati-hati dalam mengelola harta benda dan mengunakannya secara tepat dan berguna. Sedekah adalah bentuk syukur seorang hamba kepada Allah SWT atas anugerah nikmat yang diberikan oleh-NYA dengan cara yang tepat dengan memanfaatkan harta benda dalam hal kebaikan

Saat ini ketika memiliki rejeki yang lebih untuk beramal masyarakat Bandung bisa menyalurkannya melalui sebuah etalase dengan tinggi 1 meter dan lebar $50 \mathrm{~cm}$ untuk menyimpan nasi bungkus atau nasi kotak dengan lauk pauknya serta air mineral. Etalase yang diberi nama Tempat Nasi Gratis atau TNG yang berada di Bandung ditempatkan dilokasilokasi yang strategis dengan konsep siapapun boleh mengambil dan siapapun boleh mengisi. Nasi kotak yang tersedia dietalase, tidak hanya untuk masyarakat miskin kota, melainkan warga yang kehabisan uang, ataupun warga yang kesulitan mendapatkan makanan saat di perjalanan. Gerakan sosial baru ini digagas oleh seorang warga Bandung bernama Rochsan rudyanto pada akhir Oktober 2018.

\section{Proses Awal Terbentuknya Tempat Nasi Gratis Bandung (TNG)}

Gerakan sosial mempunyai tujuan untuk merubah keadaan sosial yang lebih baik. Dalam hal ini gerakan Tempat Nasi Gratis (TNG) juga mempunyai tujuan mengajak manusia kepada kebaikan dan membantu kepada sesama. Bersedekah akan menyadarkan manusia, bahwa harta yang ada pada diri manusia sesungguhnya tidak seluruhnya haknya, namun hak orang lain. Harta yang menjadi hak orang lain itu perlu di sampaikan kepada yang berhak dengan cara bersedekah.

Sedekah dalam pengertian secara umum adalah memberi sesuatu kepada orang lain. Sedekah bisa berupa materi maupun non materi, bahkan dengan memberi senyuman kepada orang lain sudah bisa dikategorikan memberikan sedekah. Agama lain pun mengajarkan sedekah yang perwujudannya sama, namun sedekah hanya dipakai dalam Islam, agama Kristiani dalam memberi sedekah mengunakan kata Kasih, Hindu memberikan sedekah mengunakan kata

Dharma, bahkan dalam kepercayaan-kepercayaan kuno para Dewa diberi sedekah yang dinamakan dengan Sesajen. Landasan sekuler memberi sedekah adalah Humanisme. Ajaran

62 SOSIOGLUBAL : Jurnal Pemikiran dan Penelitian Sasiolagi, Vol. 3, No. 2, Juni 2019 
sedekah itu bukan murni atau bukan semata-mata menjadi ajaran Islam saja, namun sudah menjadi ajaran yang bersifat unifersal (Muhyidin, 2008)

Tempat Nasi Gratis (TNG) merupakan sebuah konsep sederhana, berbagi pada sesama. Viralnya TNG yang digagas oleh Rochsan Rudhyanto di Kota Bandung pada awal November 2018 lalu, menjadi inspirasi banyak orang untuk turut andil dalam pengadaan etalase Tempat Nasi Gratis tersebut.Ide tentang Tempat Nasi Gratis awal mulanya saat Rochsan Rudyanto melihat gerakan serupa di beranda media sosial Facebook miliknya ia melihat sebuah foto yang menampilkan etalase bertuliskan "tempat nasi gratis". Rochsan mendapati foto itu pada 17 Oktober 2018 tetapi dia tak mengetahui berasal dari daerah mana lokasi "tempat nasi gratis" itu.Akhirnya, setelah melihat dan membaca penjelasan dari foto tersebut, Rochsan tertarik dengan konsep dan tagline-nya yaitu siapapun boleh mengambil, siapapun boleh mengisi, hal ini berbeda dari orang-orang yang membagikan nasi bagi masyarakat miskin karena Nasi kotak yang tersedia dietalase, tidak hanya untuk masyarakat miskin kota, melainkan warga yang kehabisan uang, ataupun warga yang kesulitan mendapatkan makanan saat di perjalanan. Kemudian rochsan mendiskusikan dengan teman-temannya untuk melakukan gerakan sosial serupa dan menghadirkannya di Bandung (Jabar.tribunnews, 2018)

Mereka kemudian menggalang dana dari 10 orang untuk membeli lemari tempat nasi gratis. Saat ini Tempat Nasi Gratis sudah ada di tiga lokasi strategis di Bandung yakni Jalan Burangrang, Jalan Wangsaniaga Kulon Tatar Wangsakerta Kotabaru Parahyangan, dan Cibodas Raya Antapani Kidul. Awalnya untuk untuk pasokan nasi dan lauk pauk, Rochsan memberdayakan katering-katering kecil rumahan untuk membeli nasi bungkus denganmenyediakan menu seharga tak lebih dari Rp12.000 per porsi dengan syarat harus enak, bersih, dan tidak cepat basi. Namun sekarang sudah banyak warga yang mendonasikan nasi bungkus atau nasi kotak ke Tempat Nasi Gratis, stiap harinya etalase TNG tidak pernah kosong dan selalu terisi nasi bungkus, roti dan air mineral dari warga sekitar.Setiap hari saat jam makan siang banyak masyarakat yang berhenti untuk mengambil makanan di dalam etalase mulai dari petugas keamanan, petugas parkir, petugas kebersihan, ibu-ibu yang sedang lewat atau bahkan karyawan kantor yang sedang beristirahat kerja. Tempat Nasi Gratis ini menjadi gerakan sosial baru yang sangat bermanfaat dan mengunggah rasa kemanusiaan untuk membantu sesama, tidak dengan membagikan nasi tetapi berbagi kebahagiaan melalui sebungkusnasi.

Saat ini sudah ada website khusus yang dibuat oleh infobdg dimana hal ini dimaksudkan untuk membuat lebih banyak lagi etalase tempat nasi gratis bandung di beberapa wilayah dan bisa mempermudah bagi siapa saja yang ingin mendonasikan sebagian uangnya untuk berpartisipasi 
dalam gerakan tempat nasi gratis Bandung melalui situs www.kitabisa.com sejak November 2018. sampai 16 Maret 2019, Infobdg telah berhasil mengumpulkan dana sebesar Rp 5.472 .952 dari 66 donatur melalui situs kitabisa.com, serta Rp 1.655 .000 dari empat donatur yang menghubungi pihak Infobdg secara langsung. Jadi, total dana yang telah dikumpulkan adalah sebanyak Rp 6.927.952. Ide tempat nasi gratis bandung telah banyak idadopsi oleh masyarakat didaerah-daerah lain hal ini menjadi sangat bermanfaat dalam memotivasi untuk berbuat kebaikan berbagi kebahagiaan kepada sesama yang membutuhkan (Infobdg, 2019).

\section{SIMPULAN}

Semua orang dapat melakukan kegiatan gerakan sosial dengan cara apa pun. Salah satunya dengan bersedekah nasi, berbagi kebahagiaan dengan sesama. Saat ini ketika memiliki rejeki yang lebih untuk beramal masyarakat Bandung bisa menyalurkannya melalui sebuah etalase dengan tinggi 1 meter dan lebar $50 \mathrm{~cm}$ untuk menyimpan nasi bungkus atau nasi kotak dengan lauk pauknya serta air mineral. Etalase yang diberi nama Tempat Nasi Gratis atau TNG yang berada di Bandung ditempatkan dilokasi-lokasi yang strategis dengan konsep siapapun boleh mengambil dan siapapun boleh mengisi. Nasi kotak yang tersedia dietalase, tidak hanya untuk masyarakat miskin kota, melainkan warga yang kehabisan uang, ataupun warga yang kesulitan mendapatkan makanan saat di perjalanan. Gerakan sosial baru ini digagas oleh seorang warga Bandung bernama Rochsan rudyanto pada akhir Oktober 2018.Saat ini Tempat nasi gratis Bandung telah banyak ditiru diberbagai daerah, seperti Tempat nasi gratis Jogja, Tempat nasi gratis Serang, Tempat nasi gratis Makassar dll. Gerakan sosial baru ini telah banyak menginspirasi masyarakat diberbagai daerah diIndonesia untuk berbagi kepada yang membutuhkan.

\section{DAFTAR PUSTAKA}

Budiarjo, M. (2010). Dasar-dasar Ilmu Politik. Jakarta: PT.Gramedia Utama Pustaka.

Cohen, Jean L. 1985. Class and Society: The Limits of Marxian Critical Theory. Amherest: Massachusett Press.

Iskandar. 1994. Sedekah Membuka Pintu Rezeki. Bandung: Pustaka Islam.

Kamanto Sunarto. 2004. Pengantar Sosiologi (Edisi Revisi),. Jakarta: FE UI.

Muhammad bin Salih. 2008. Fatwa-fatwa Zakat. Jakarta:Darus Sunnah.

Purboningsih, S. D. 2015. Gerakan Sosial Baru Perspektif Kritis: Relawan Politik Dalam Pilpres 2014. Jurnal Review Politik, Vol 05, No, 100-125.

Robert Mirsel. 2004. Teori Pergerakan Sosial: Kilasan Sejarah dan Catatan Bibliografis. Jakarta: Resist Book.

Rahmat, A. 2017. Gerakan Sosial dalam Aksi Penyelenggaraan Sekolah untuk Anak Miskin. MASYARAKAT: Jurnal Sosiologi, 19(1), 27-56.

64 SOSIOGLIBAL : Jurnal Pemikiran dan Penelitian Sosiologi, Vol. 3, No. 2, Juni 2019 
https://doi.org/10.7454/mjs.v19i1.4675.

Singh, R. S. 2010.Gerakan Sosial Baru. Yogyakarta: Resist Book.

Suharko. 2006. Gerakan Sosial Baru di Indonesia: Repertoar Gerakan Petani. Jurnal Ilmu Sosial Dan Ilmu Politik, 10(1), 1-34. https://doi.org/10.22146/JSP.11020.

Sugiyono. 2012. Metode Penelitian Kualitatif Kuantitatif dan RひD. Bandung: Alfabeta.

Touraine, Alain. 1973. The Self Production of Society. Chicago: University of Chicago Press.(diterjemahkan oleh Derek Coltman, dari Bahasa Perancis Production de la societe, Paris, Seuil, 1973).

Yulius, Y. 2018. Tempat nasi gratis bandung, yang mau nyumbang silabkan simpan, yang mau makan silabkan ambil. Jabar.tribunnews. Retrieved from: http://jabar.tribunnews.com/2018/11/07/tempat-nasi-gratis-bandung-yang-maunyumbang-silakan-simpan-yang-mau-makan-silakan-ambil?page $=3$

Martiyanti, E.2018). Tempat Nasi Gratis Bandung Siapa Saja Boleh Isi atau Ambil. Jawapost.com. Retrieved from: https://www.jawapos.com/jpg-today/07/11/2018/tempat-nasigratis-di-bandung-siapa-saja-boleh-isi-atau-ambil/

www.infobdg.com: http://www.infobdg.com/v2/nasi-gratis-bdg-semua-bisa-mengambilsemua-bisa-mengisi/ 